\title{
16
}

\section{Present and Future Fluvial, Tidal and Storm Surge Flooding in Coastal Bangladesh}

\section{Anisul Haque, Susan Kay, and Robert J. Nicholls}

\subsection{Introduction}

Inundation in coastal Bangladesh can be caused by a number of flood drivers as explained in Chap. 8: (i) fluvial floods, (ii) tidal floods, (iii) fluvio-tidal floods and (iv) storm surge floods. The dominance of a specific flood driver depends on location. The first three types of flooding can occur at the same time under monsoon conditions and during spring tides. Fluvial and fluvio-tidal floods are linked to the monsoon and can persist for weeks or longer, whereas a tidal flood is a short-term (daily)

\section{A. Haque $(\bowtie)$}

Institute of Water and Flood Management, Bangladesh University of Engineering and Technology, Dhaka, Bangladesh

S. Kay

Plymouth Marine Laboratory, Plymouth, UK

R. J. Nicholls

Faculty of Engineering and the Environment and Tyndall Centre for Climate Change Research, University of Southampton, Southampton, UK 
flood linked to tidal fluctuations. Storm surge flooding is caused by the landfall of tropical cyclones in coastal Bangladesh (Chap. 14).

In this research, quantitative information on the magnitude and extent of all these flood types both today and through the twenty-first century is developed using a hydrodynamic numerical model together with a series of scenarios. This chapter describes the methods, the main findings and characteristics of the dominant present and future flooding patterns in the coastal region. It analyses the fluvial, tidal and fluvio-tidal flooding using one model framework, while flooding due to cyclones is considered independently.

\subsection{Analysis of Fluvial, Tidal and Fluvio-tidal Flooding}

In this section, the occurrence of fluvial, tidal and fluvio-tidal floods in coastal Bangladesh are analysed. These floods occur during the monsoon season, when the three types of flooding can occur simultaneously, although the relative severity depends on location. Generally tidal flooding occurs close to the coast, whereas fluvial flooding occurs further inland along the rivers and estuaries. Where fluvial flooding is influenced by the tide, the flood is characterised as a compound fluvio-tidal flood (Chap. 8).

To analyse the extent of flooding in the region, a well-known opensource numerical model (Delft 3D Flow) was applied. In the model, the study region is represented by all the rivers and estuaries of the coastal zone which have a width greater than $100 \mathrm{~m}$. Fluvial flows enter the model domain through three major rivers-Ganges, Brahmaputra and Upper Meghna (see Chap. 8, Fig. 8.1). For all present-day conditions simulated by the model, measured discharges from the Bangladesh Water Development Board (BWDB) are specified in these three locations, whereas, for all future scenarios, discharges in these locations are provided from the simulation results of the hydrological model, INCA (Whitehead et al. 2015a, b; see Chap. 13). As measured data for the sea level is not available, sea level variation is provided from the simulation 
results of an ocean model GCOMS (see Chap. 14) for both present-day conditions and future scenarios. The region is discretised into 896,603 grid points, where the grid size varies from 243 to $1,164 \mathrm{~m}$ in the longitudinal direction and 186 to $1,704 \mathrm{~m}$ in the lateral direction. The coarser grid size is used in the ocean, and the finer grid size is used for the land areas to capture the details of the river/estuarine systems and topographic variation.

Topography in the model is provided by the digital elevation model (DEM) available in the database of Water Resources Planning Organisation (WARPO). The DEM in its current form has a $50 \times 50 \mathrm{~m}$ resolution. For the river bathymetry, combinations of secondary and primary data are used. Secondary data are collected from BWDB, and primary data for 294 locations along the rivers/estuaries of the coastal zone are measured as part of this research. Ocean bathymetry is provided from the open access General Bathymetric Chart of the Oceans (GEBCO). The coastal zone in Bangladesh contains 139 polders, of which 103 are in the study area. In the model, polder locations are specified from the polder map available in the WARPO database, and design polder heights are specified from the data collected from BWDB. Subsidence and morphological changes (bank line shifting, bed level changes and floodplain sedimentation) are not considered in any of the flood simulations. However, wetting and drying phenomena are considered during the rise and recession phases of fluvial floods, during rising and falling tides of tidal floods and during the landfall and decay stages of cyclone generated storm surge floods. The model is calibrated for a base year condition (year 2000) and validated for present-day extreme condition (year 1998). With a simulation time step of ten minutes, total run time for one-year flood model simulation is 48 hours using a $\mathrm{PC}$ with core i7 processor and $32 \mathrm{MB}$ RAM. A discussion on model calibration and validation can be found in Haque et al. (2016).

The present-day conditions and future scenarios are shown in Table 16.1. The present-day conditions (base year for average condition and present-day extreme for a high fluvial flood year) are classified following the BWDB definition of flooding (see Chap. 8 and BWDB 2012). Future flooding scenarios are based on the scenario descriptions 


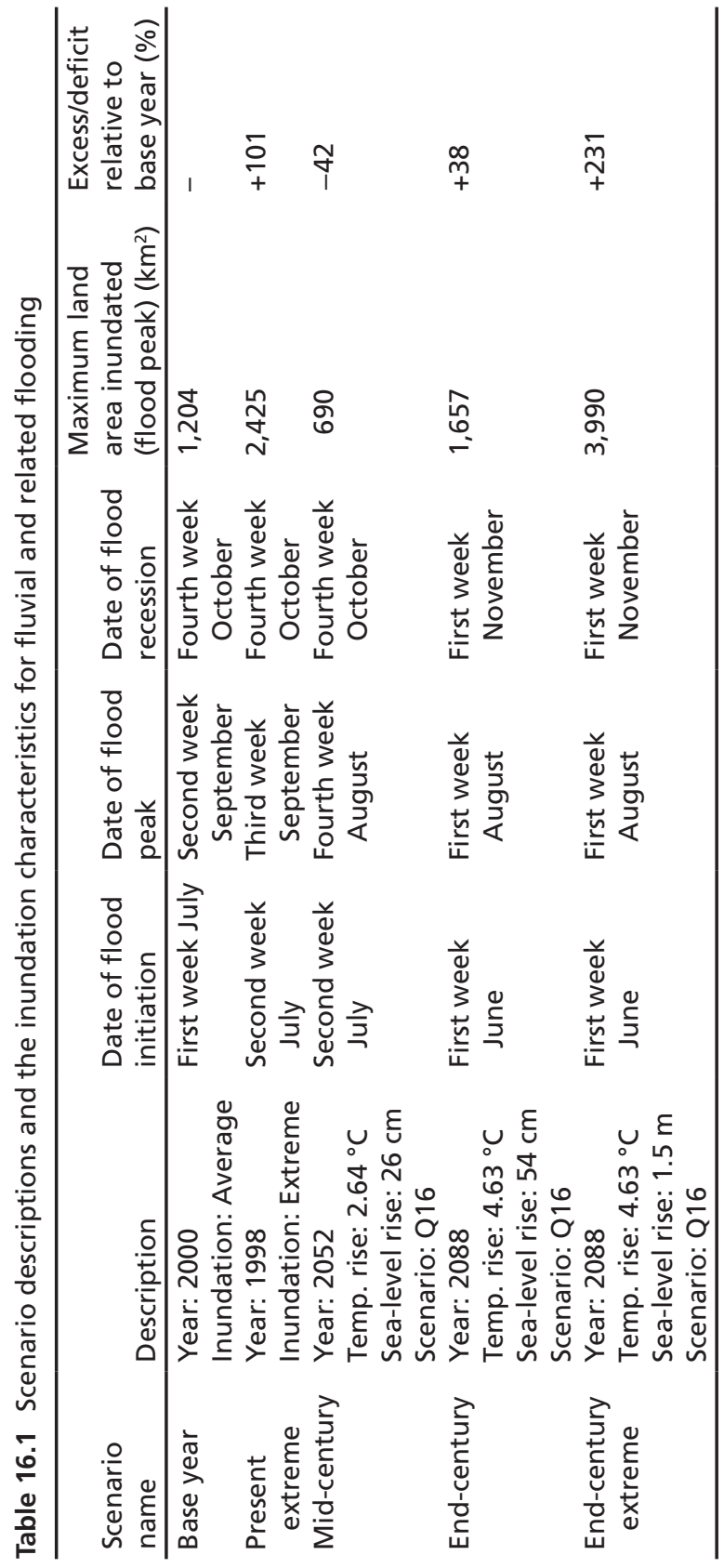


and quantification undertaken during the project (Chaps. 9, 11 and 14). In total there are five simulations for fluvial and related flooding and five simulations for storm surge flooding due to cyclonic events.

Sea-level rise projections for these scenarios were based on the Fifth Assessment Report of the Intergovernmental Panel on Climate Change (AR5, Church et al. 2013, see also Chap. 14). Mid-century rise was taken as $0.24 \mathrm{~m}$, compared to a baseline in 2000 , and end-century rise as $0.54 \mathrm{~m}$. The $0.54 \mathrm{~m}$ value is quite conservative and in particular omits any potential contribution from melting of the West Antarctic ice sheet. The extreme end-century value used in some simulations in this chapter, $1.5 \mathrm{~m}$, is based on the high-end estimates from AR5 with an additional $0.5 \mathrm{~m}$ for ice sheet melting (Kay et al. 2015). Subsidence is added to local sea-level rise but has not been included in the research presented due to the uncertainty in predicting subsidence in protected and non-protected land. However, subsidence rates are estimated to be of the order $2.5 \mathrm{~mm} /$ year (Brown and Nicholls 2015) so could add an additional $0.25 \mathrm{~m}$ by the end of the century (see also Chap. 15).

The areal extent of inundation due to these present and future conditions is given in Table 16.1. Compared to the base year condition, the present-day extreme flood is doubled in the inundated area. The presentday extreme flood condition corresponds roughly to a flood with 100 year return period (Islam and Chowdhury 2002). In the future there is a tendency for a large increase in flooded area, but not in all cases. By the end of the century (end-century extreme scenario), the flooded area increases by 231 per cent compared to the base year and 65 per cent compared to the present extreme. This scenario might cause overtopping of the coastal embankments (Nihal et al. 2016), and needs further evaluation. It should be noted that while sea-level rise dominates the change, increases in upstream discharges are also significant (see Whitehead et al. 2015a, b).

Maps of the flooded areas are shown in Fig. 16.1. Unprotected areas in the north of the study area are inundated due to changes in the discharge of the upstream rivers during the monsoon season (May to October). At the onset of monsoon, river water inundates any unprotected land and rises to its peak, generally in August or September (see Table 16.1). The influence of tides is minimal in these areas, except when monsoon winds and resulting elevated sea levels during the spring tide can delay drainage 

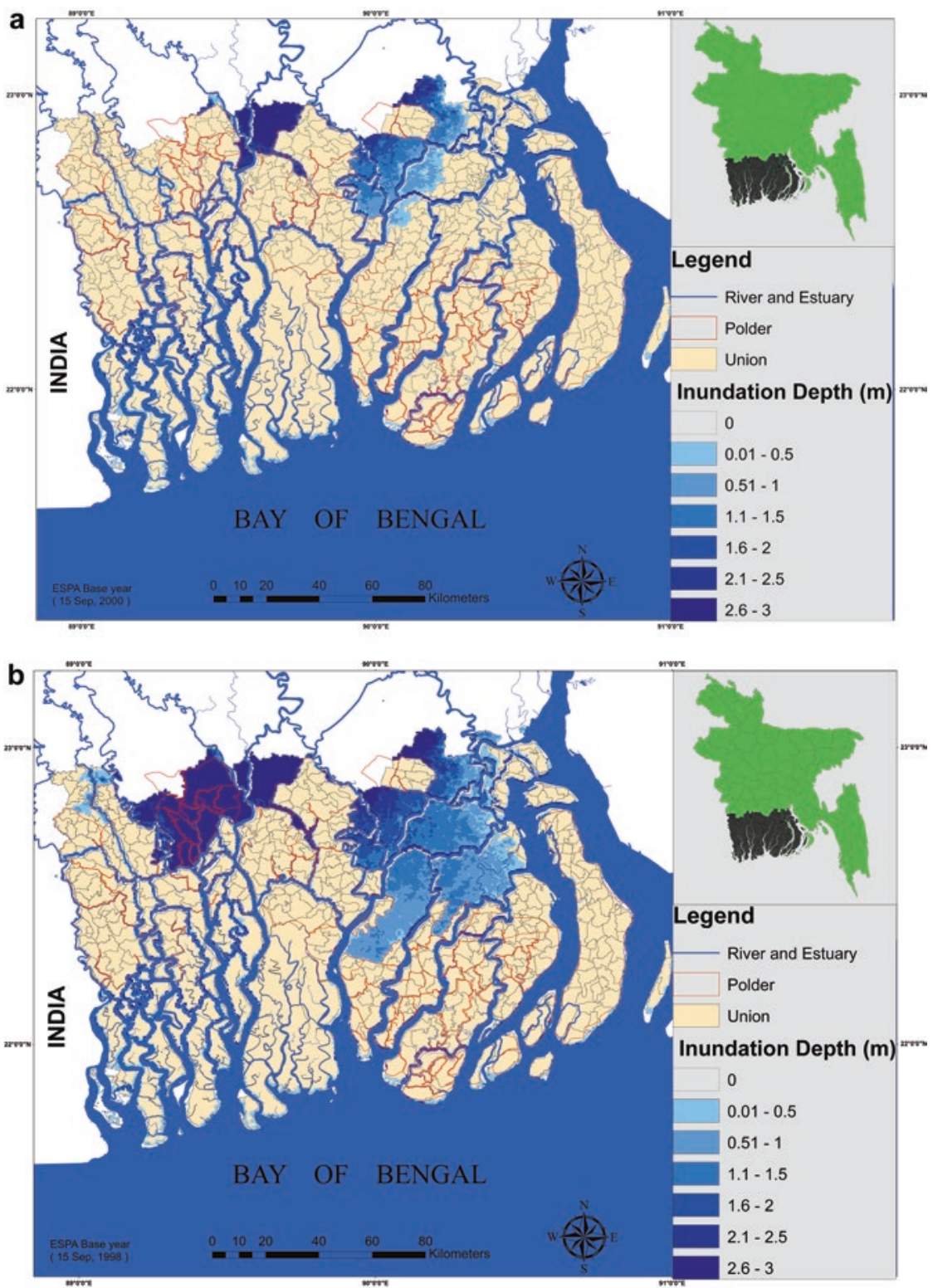

Fig. 16.1 Inundation maps for different flooding scenarios as described in Table 16.1 (a) base year, (b) present-day extreme, (c) mid-century, (d) end-century, (e) end-century extreme 

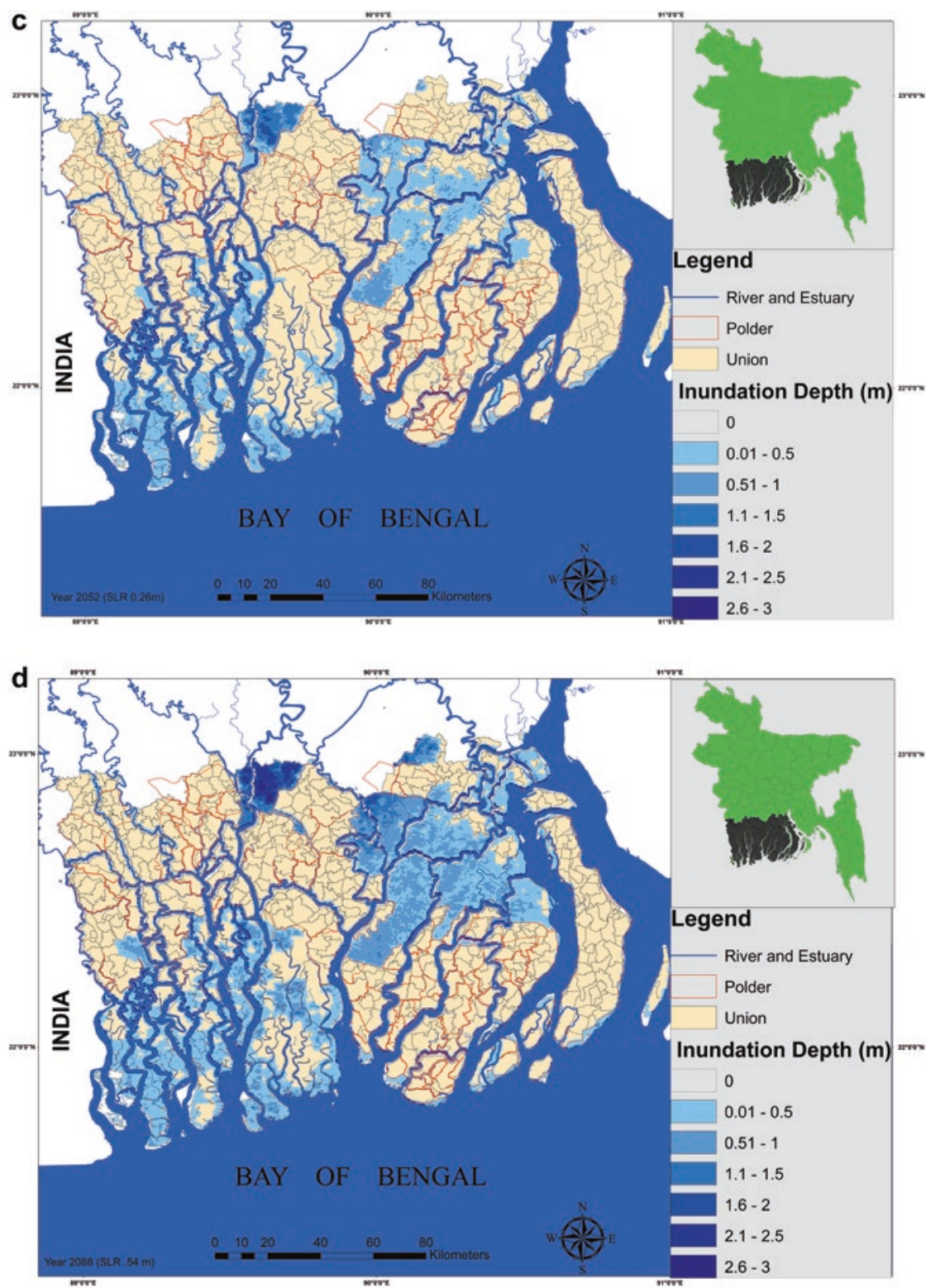

Fig. 16.1 (continued) 


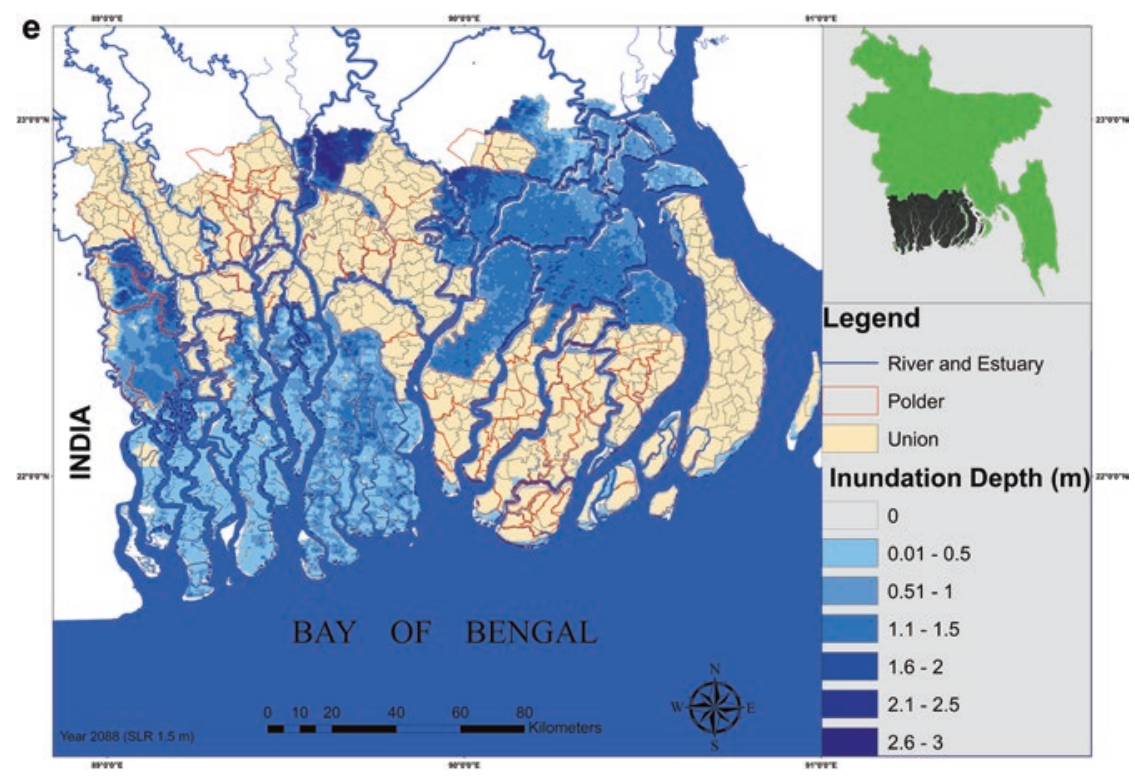

Fig. 16.1 (continued)

(Haque et al. 2002). Tidal flooding impacts unprotected areas close to the sea. The banks of the lower reaches of rivers (estuaries) are affected by regular tidal inundation. There is negligible influence of fluvial flow in these areas, and seasonal variations are not visible. Flood depths are also significantly lower than those that occur with the monsoon-related fluvial flooding (Fig. 16.2).

\subsection{Analysis of Storm Surge Flooding}

The origin and nature of storm surge flooding is distinct from fluvial, tidal and fluvio-tidal flooding. Storm surge flooding is generated by the landfall of tropical cyclones which normally occur during pre- and post-monsoon seasons (April-May and October-November), as discussed in Chap. 8. Both extreme and more frequently occurring cyclones are considered. 


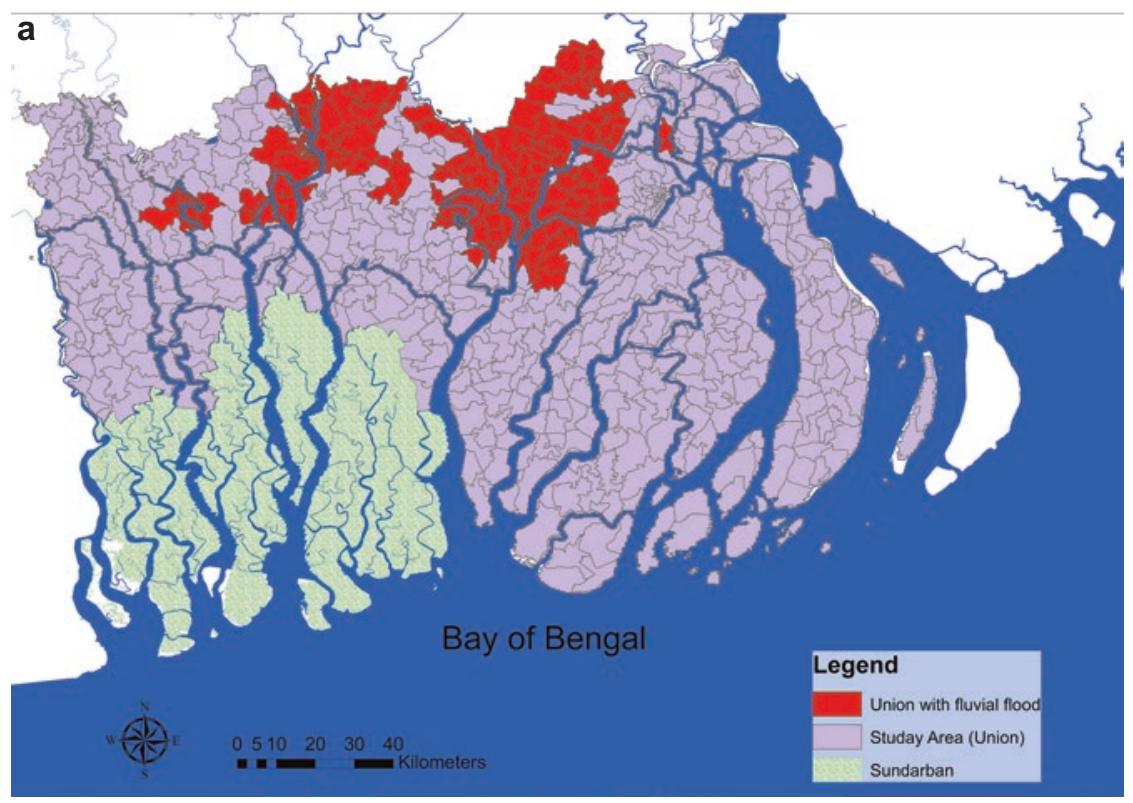

b

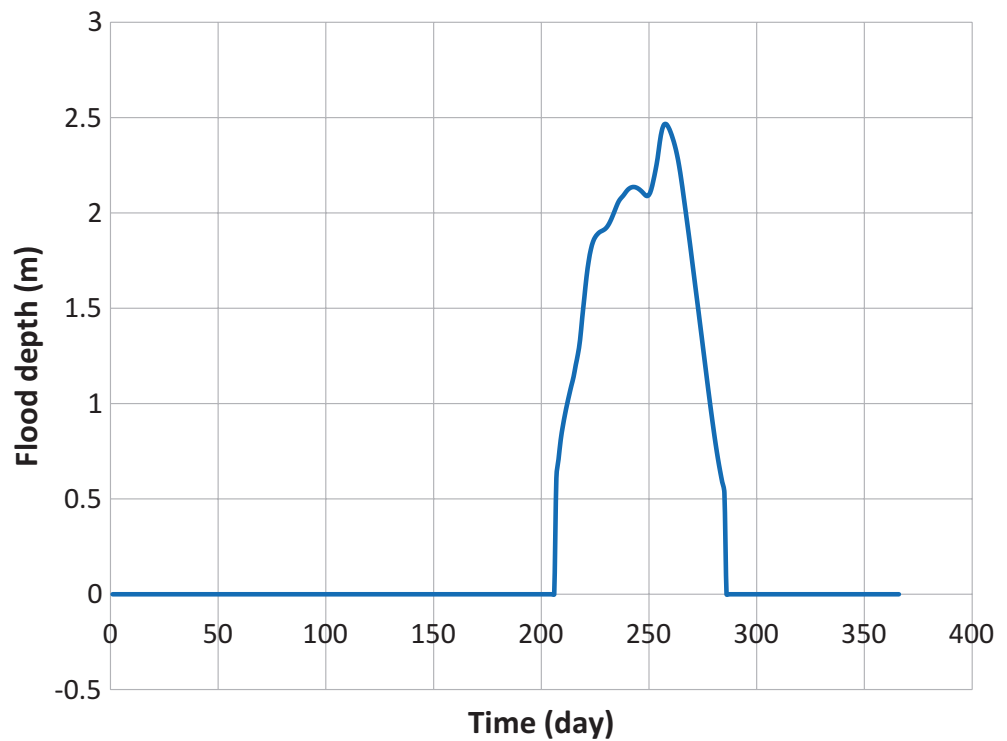

Fig. 16.2 Comparison of fluvial and tidal flooding characteristics (a) and (c) location and (b) and (d) typical hydrographs 
A. Haque et al.

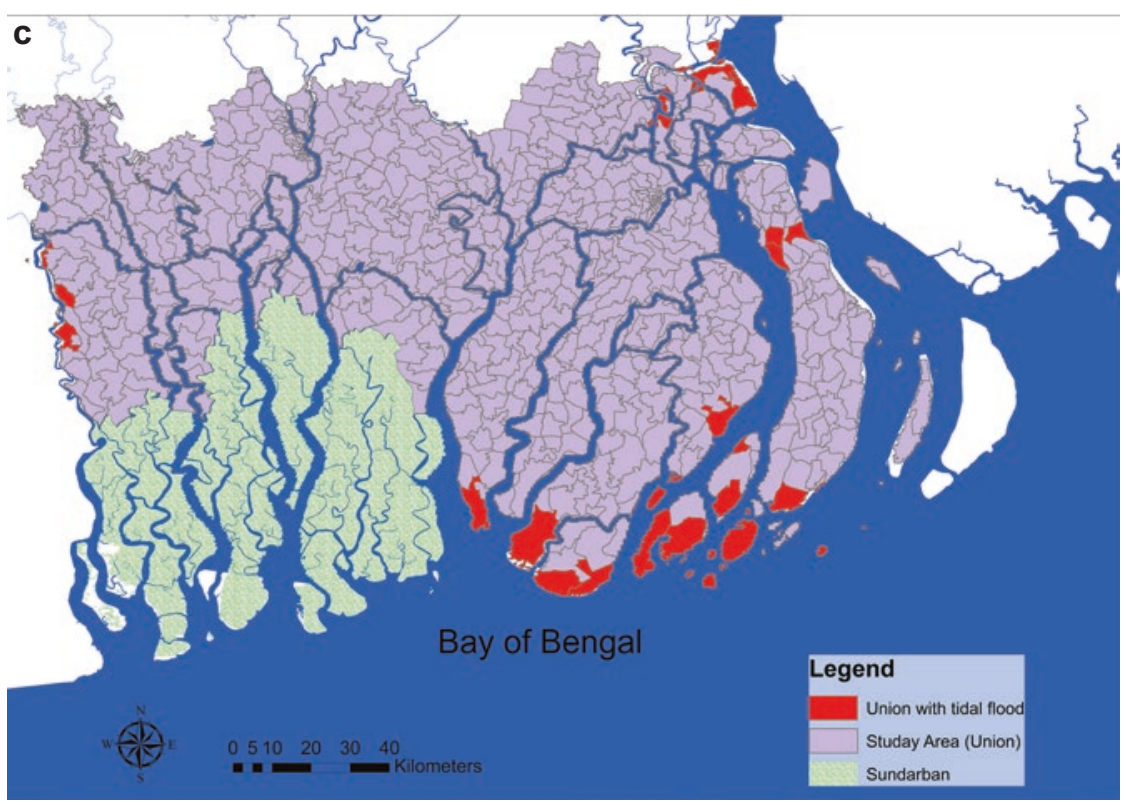

d

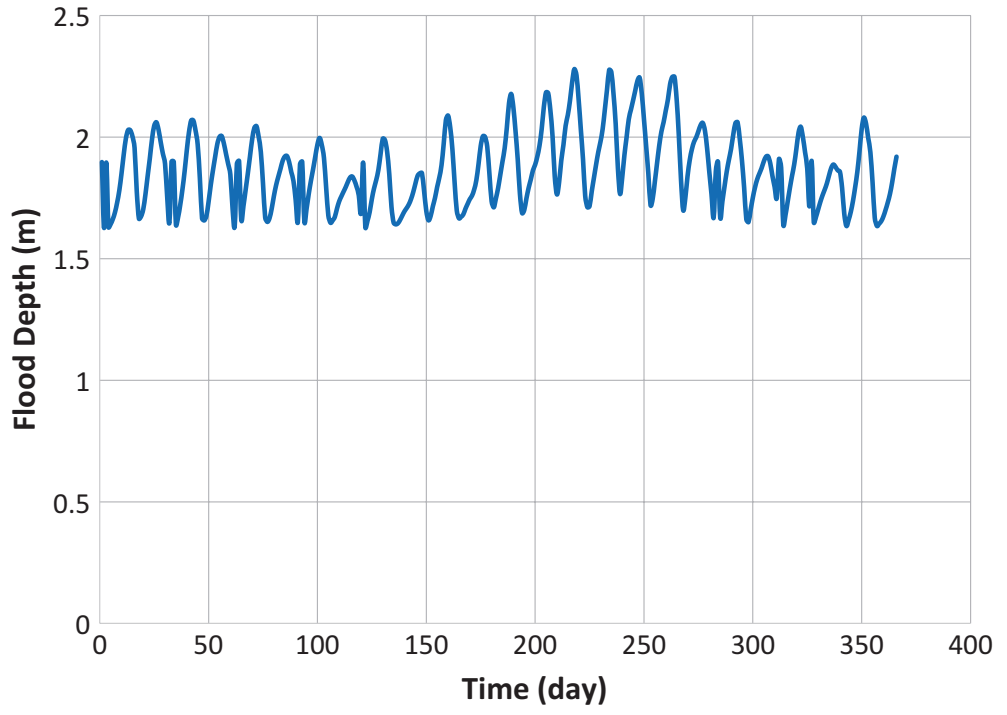

Fig. 16.2 (continued) 
Storm surges are simulated by applying a numerical model (Delft Dashboard and Delft 3D Flow) as discussed in Nihal et al. (2015). Simulating a full population of extreme events for flood analysis represent a major activity which was beyond the resources available for this research. Hence, a combination of an historical analogue approach to capture extreme events and simulation of more common cyclones is adopted. Cyclone Sidr made landfall on the Bangladesh coast on 15 November 2007 as a Category 4 Cyclone, killing more than 3,000 people in Bangladesh. It is considered to be the most severe cyclone to make landfall in Bangladesh since the 1991 surge which killed over 100,000 people (Chap. 8). Cyclone Sidr was selected as a representation of a typical high strength cyclone. Two future scenarios were also developed based on Cyclone Sidr as defined in Table 16.2 (SIDR-mid-century and SIDR-end-century).

In addition, two examples of less severe cyclone scenarios were extracted from the model analysis of cyclones and resulting extreme sea levels by Kay et al. (2015). These are generated using a shelf-sea model (POLCOMS) driven with the regional climate scenarios described in Chap. 11. They are termed GENERATED scenarios and comprise two scenarios: GENERATED-mid-century and GENERATED-end-century (Table 16.2). These modelled cyclones were characterised by low atmospheric pressure $(<965 \mathrm{mb})$ coinciding with abnormally high sea level $(>0.7 \mathrm{~m}$ above annual normal); two typical events were selected for analysis (Fig. 16.3). Flood extents were then modelled using the Delft3D model, using the shelf-sea model to provide boundary conditions at $86.414^{\circ} \mathrm{E}, 19.967^{\circ} \mathrm{N}$ and $92.9433^{\circ} \mathrm{E}, 19.9751^{\circ} \mathrm{N}$. The process of surge propagation inland through the estuaries and the land are simulated by Delft3D. Due to the structured grid and grid size (explained in Sect. 16.2), the complex geometrical variation of the coast is largely linearised. This means that localised flood effects due to local physical settings (e.g. road and canal network inside poldered area) are not always captured by the model, but it provides a useful national case study of how extreme sea-level events may develop due to twenty-first century climate change for coastal Bangladesh.

The modelled GENERATED cyclones have lower wind speeds than the modelled Cyclone SIDR (Fig. 16.4) and landfall locations to the west 
Table 16.2 Scenario descriptions, inundated area and the maximum surge depth due to selected present and potential cyclonic events

\begin{tabular}{|c|c|c|c|c|}
\hline Cyclone & Description & $\begin{array}{l}\text { Total area } \\
\text { inundated } \\
\left(\mathrm{km}^{2}\right)\end{array}$ & $\begin{array}{l}\text { Excess/ } \\
\text { deficit } \\
\text { compared } \\
\text { to SIDR }(\%)\end{array}$ & $\begin{array}{l}\text { Maximum } \\
\text { flood } \\
\text { depth }(m)\end{array}$ \\
\hline $\begin{array}{l}\text { SIDR (base } \\
\text { case) }\end{array}$ & $\begin{array}{l}\text { Cyclone SIDR made } \\
\text { landfall east of the } \\
\text { Sundarbans on } 15 \\
\text { November } 2007\end{array}$ & 914 & - & 5.6 \\
\hline $\begin{array}{l}\text { SIDR-mid- } \\
\text { century }\end{array}$ & $\begin{array}{l}\text { A SIDR-like cyclone } \\
\text { (similar strength and } \\
\text { landfall location) with } \\
\text { hydrodynamic setting } \\
\text { as the mid-century } \\
\text { scenario Q16 with } \\
26 \mathrm{~cm} \text { SLR (Table 16.1) }\end{array}$ & 2,063 & +125 & 5.9 \\
\hline $\begin{array}{l}\text { SIDR-end- } \\
\text { century }\end{array}$ & $\begin{array}{l}\text { A SIDR-like cyclone } \\
\text { (similar strength and } \\
\text { landfall location) with } \\
\text { hydrodynamic setting } \\
\text { as the end-century } \\
\text { scenario Q16 with } \\
54 \mathrm{~cm} \text { SLR (Table 16.1) }\end{array}$ & 3,491 & +282 & 6.0 \\
\hline $\begin{array}{l}\text { GENERATED- } \\
\text { mid-century }\end{array}$ & $\begin{array}{l}\text { Cyclone scenario } \\
\text { extracted from the Bay } \\
\text { of Bengal POLCOMS } \\
\text { Model. A specific } \\
\text { cyclone from year } 2062 \\
\text { (low temperature rise } \\
\text { and 26-cm sea-level rise } \\
\text { which is a Q16 scenario) } \\
\text { is selected }\end{array}$ & 1,305 & +42 & 4.2 \\
\hline $\begin{array}{l}\text { GENERATED- } \\
\text { end-century }\end{array}$ & $\begin{array}{l}\text { Cyclone scenario } \\
\text { extracted from the Bay } \\
\text { of Bengal POLCOMS } \\
\text { Model. A specific } \\
\text { cyclone from year } 2088 \\
\text { (high temperature rise } \\
\text { and } 54 \mathrm{~cm} \text { sea-level rise } \\
\text { which is a Q16 scenario) } \\
\text { is selected }\end{array}$ & 690 & -24 & 4.6 \\
\hline
\end{tabular}




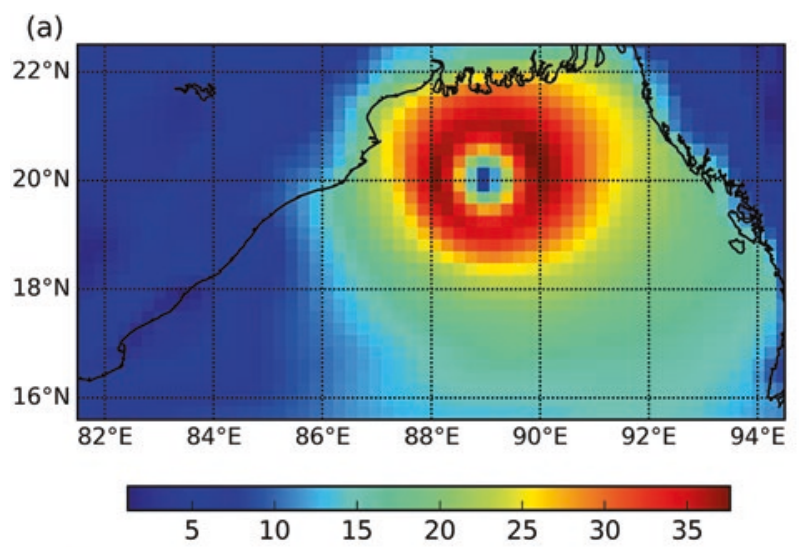

(b)

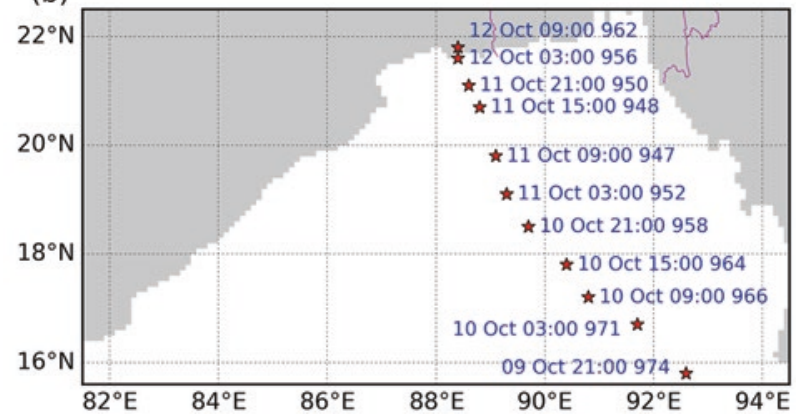

Fig. 16.3 Example of a simulated cyclone event, October 2028. (a) Wind speed $(\mathrm{m} / \mathrm{s})$ at 09:00 on 11 October. (b) Minimum pressure at 6 hourly intervals from 9 October 15:00 to 12 October 03:00 2028. Data is taken from the simulations described in Kay et al. (2015)

of SIDR (mid-century cyclone at the western boundary of the Sundarbans and end-century cyclone in the Indian section of the Sundarbans). These differences influence the total inundated area and flood depth-the GENERATED-mid-century inundates an area 42 per cent greater than Cyclone SIDR (compared to 125 per cent greater area for a SIDR-midcentury cyclone), whereas the GENERATED-end-century cyclone floods an area 24 per cent smaller (compared to 282 per cent greater area for a SIDR-end-century cyclone). The maximum flood depth of the GENERATED cyclones produces a smaller flood depth (around $4.5 \mathrm{~m}$ ) 


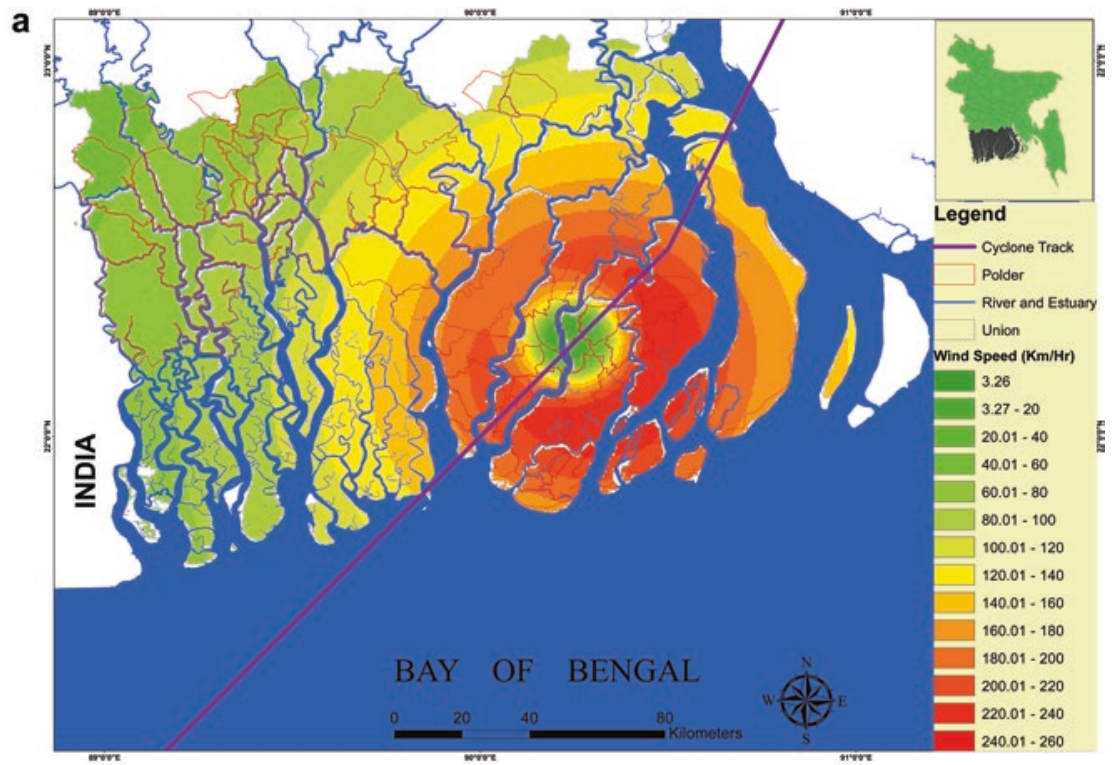

b

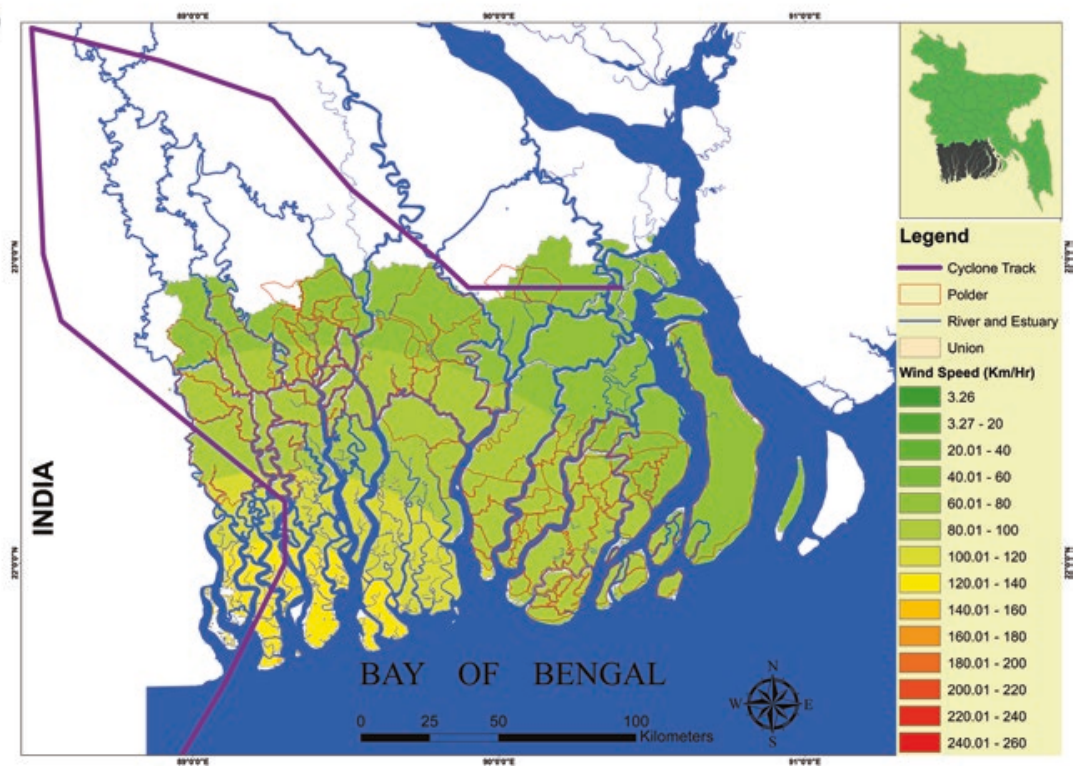

Fig. 16.4 Wind speed during cyclone events for (a) SIDR, (b) GENERATED-midcentury, (c) GENERATED-end-century scenarios 


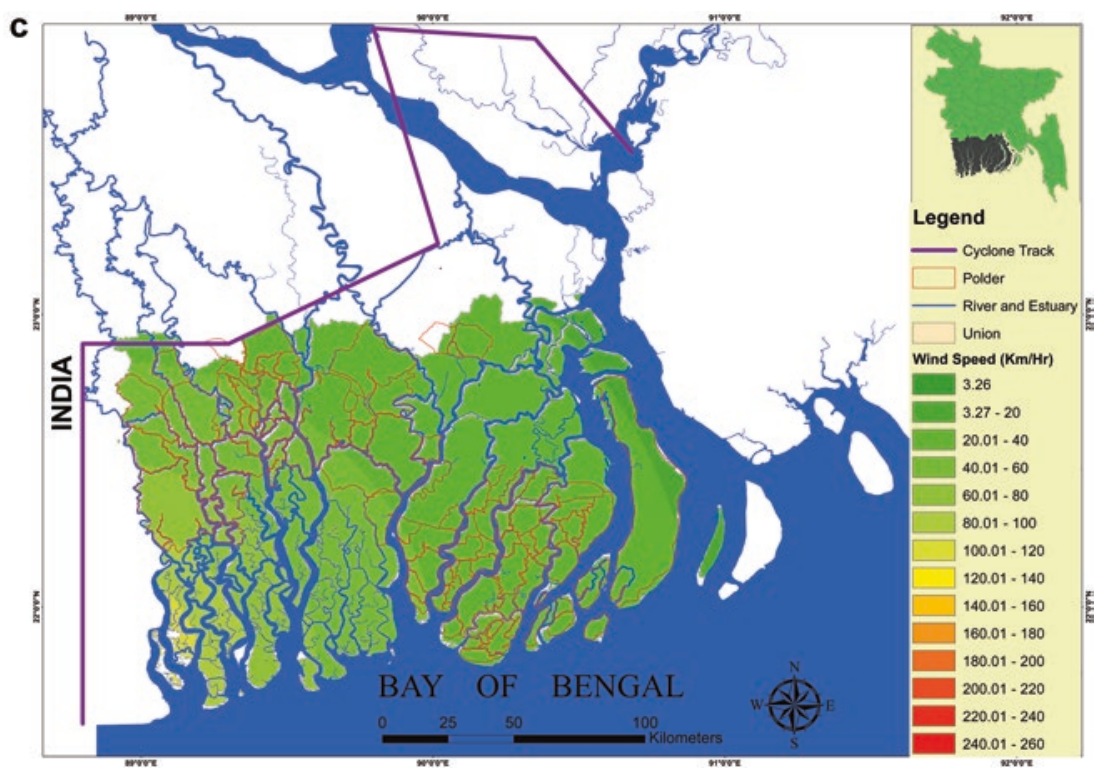

Fig. 16.4 (continued)

compared to SIDR-strength cyclones (around $6 \mathrm{~m}$ ). So the modelling suggests that, with a moderate estimate of sea-level rise, weaker cyclones at end-century may still produce lower flood depths than extreme events in the present day.

The inundation associated with extreme storm surges is shown in Fig. 16.5 and reported in Table 16.2. Cyclones SIDR, SIDR-mid-century and $S I D R$-end-century have similar cyclone wind speed, pressure drop and landfall locations. A cyclone with $S I D R$ strength and in the same landfall location in mid-century floods an extra 125 per cent of land, mainly due to sea-level rise (see Table 16.2). The corresponding increase of maximum flood depth is $30 \mathrm{~cm}$. Similarly, by end-century, the land that is inundated is nearly quadrupled combined with an increase of $33 \mathrm{~cm}$ to maximum surge height under $54 \mathrm{~cm}$ sea-level rise.

Other similar studies show the importance of landfall location of cyclones on the extent of land inundation, in addition to sea-level rise 

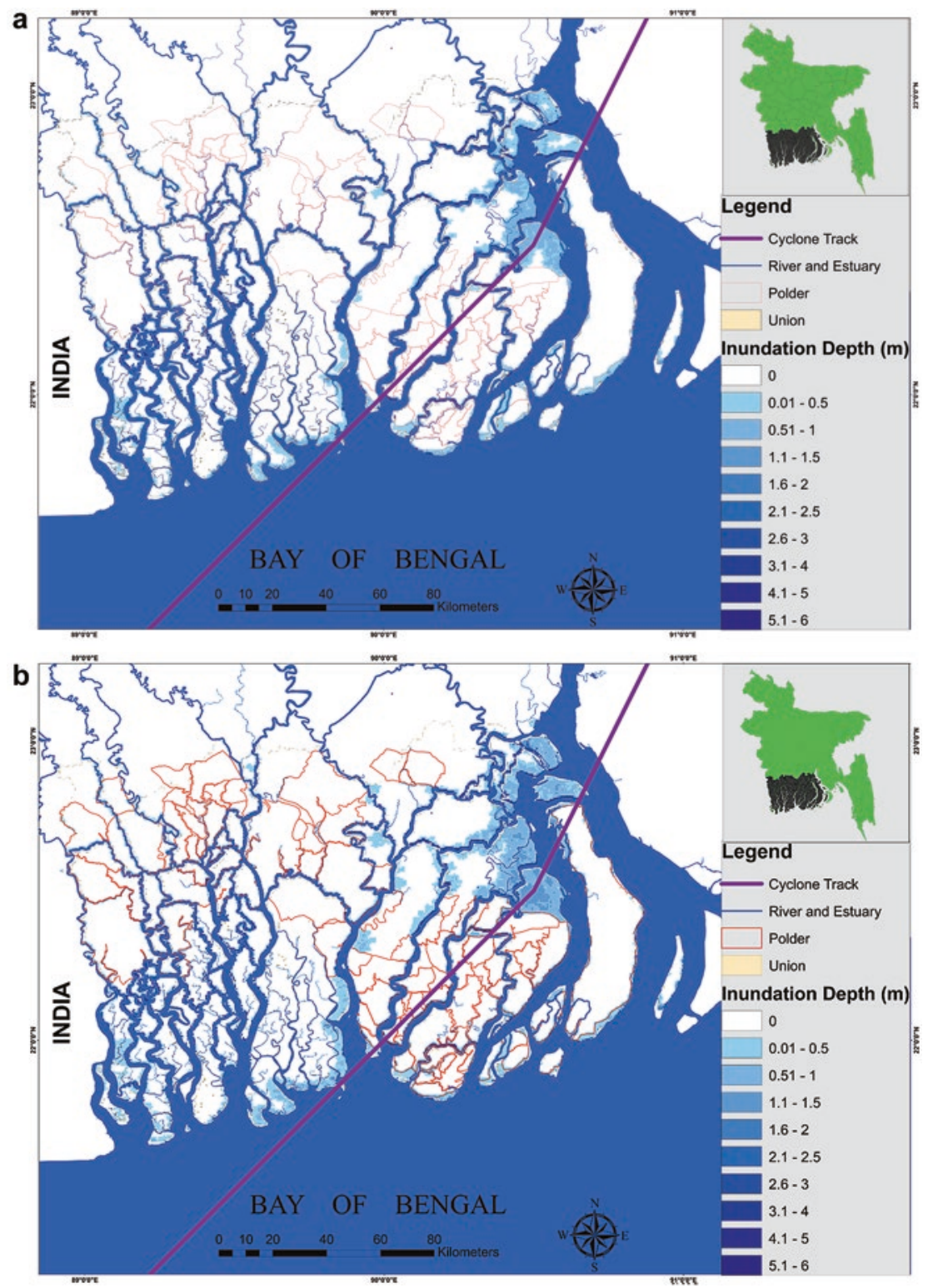

Fig. 16.5 Flood (or inundation) depth and inundated areas of cyclones (a) SIDR, (b) SIDR-mid-century, (c) SIDR-end-century, (d) GENERATED-mid-century and (e) GENERATED-end-century scenarios 

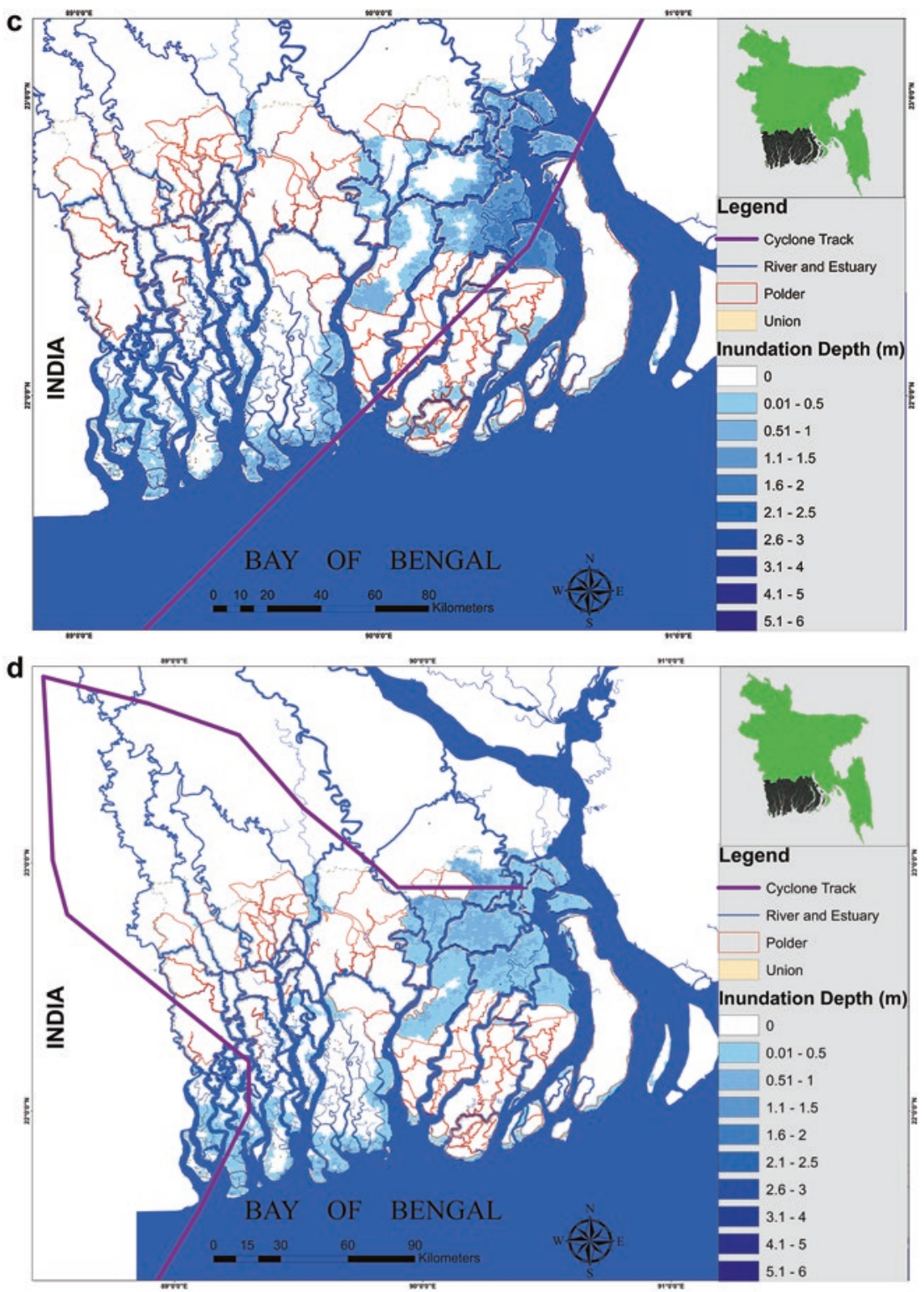

Fig. 16.5 (continued) 


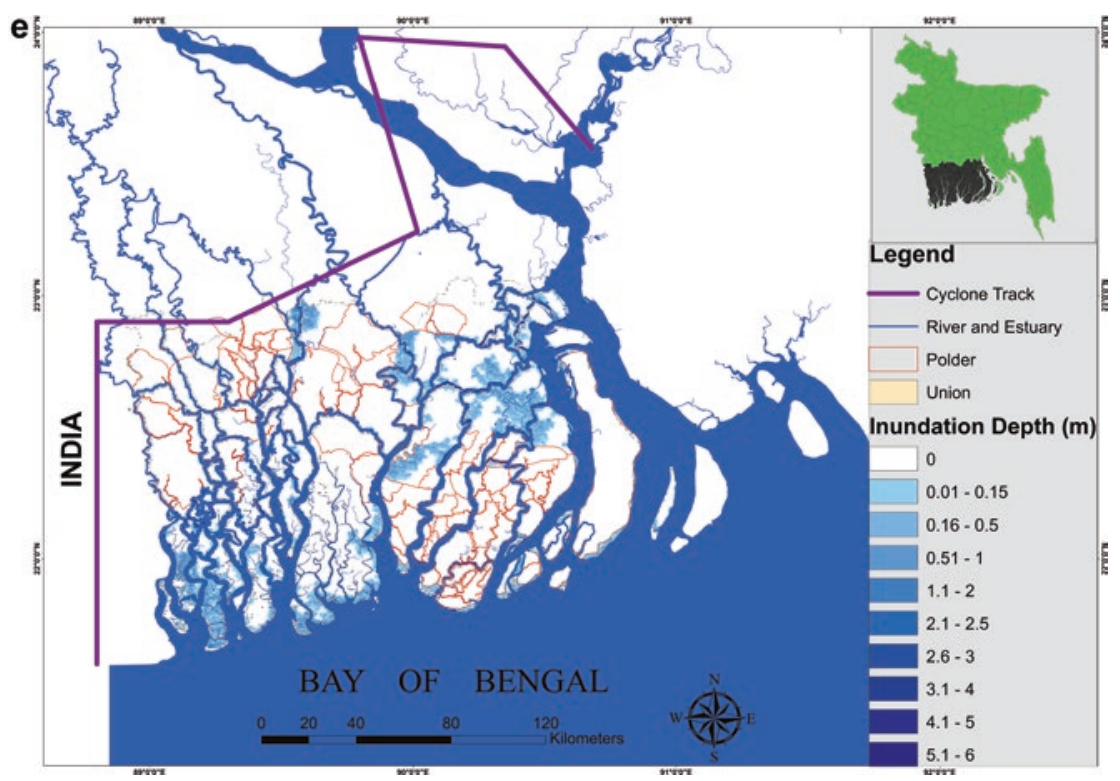

Fig. 16.5 (continued)

and wind speed. When a cyclone makes landfall in the Sundarbans, the mangroves act as a buffer which reduces the extent of land inundation (see Sakib et al. 2015). Another study shows that due to net land subsidence, cyclone landfall in the central region is more vulnerable compared to other regions (Nihal et al. 2015).

\subsection{Discussion and Conclusions}

Fluvial floods occur from July to October, and the flood area is confined to the northern part of the coastal region. Tidal floods occur in the southern part of the coastal region along the banks of the estuaries and tend to last less than a day. The magnitude of the land inundation due to fluvial and tidal flood is aggravated over the twenty-first century by sea-level rise and larger upstream river flows. In an extreme present-day flood situation (e.g. for a 100-year flood), total inundated area is approximately 101 per 
cent more than an average situation. Due to sea-level rise and change in upstream river flows, this value may rise up to 231 per cent (for an endcentury scenario with a $1.5 \mathrm{~m}$ sea-level rise). Some specific future flood events cause overtopping of coastal embankments.

Storm surge floods in the region are caused by the landfall of tropical cyclones, which normally occur April to May (pre-monsoon) and October to November (post-monsoon). The areal extent of inundation and flood depth due to storm surge depends on the cyclone wind speed, landfall location and landfall time (Chap. 8). Sea-level rise generally increases the area of land inundation. A $S I D R$-strength cyclone repeated in midcentury with a sea-level rise of $26 \mathrm{~cm}$ increases the area of land inundation by 125 per cent. A similar cyclone at the end-century, with a sea-level rise of $54 \mathrm{~cm}$, increases the area of land inundation by 282 per cent. Corresponding increase of maximum flood depth is 30 and $33 \mathrm{~cm}$ in mid- and end-century, respectively. Hence, changes in cyclone-induced flooding are of greater magnitude than fluvial flooding.

The analysis shows that the effects of sea-level rise are not simple inundation as shown in the first inundation assessments of Bangladesh as published by Milliman et al. (1989) and Huq et al. (1995). This reflects the extensive polders and embankment systems that exist in coastal Bangladesh (Chap. 8). Further, the areas outside the polders, such as the Sundarbans, can accrete with the sea level (see Chap. 26). However, given the large areas potentially flooded, adaptation and planning for increased flooding are essential. More consideration needs to be given to understanding and predicting embankment breaching as this will become more likely over time if no planning is undertaken. Upgrading the embankments, as is already proposed in the Bangladesh Delta Plan 2100 is one approach, combined with other improvements such as improved warning systems (Dasgupta et al. 2014). More fundamentally there is a need to develop more sustainable long-term management techniques such as 'tidal river management'. This is controlled or engineered sedimentation within polders to build land elevation (Amir et al. 2013; Auerbach et al. 2015). It has been employed locally to date and given the large amount of natural sediment available could be employed on a much larger scale (see Chap. 15). 


\section{References}

Amir, M.S.I.I., M.S.A. Khan, M.M.K. Khan, M.G. Rasul, and F. Akram. 2013. Tidal river sediment management-A case study in southwestern Bangladesh. International Journal of Environmental, Chemical, Ecological, Geological and Geophysical Engineering 7 (3): 176-185.

Auerbach, L.W., S.L. Goodbred, D.R. Mondal, C.A. Wilson, K.R. Ahmed, K. Roy, M.S. Steckler, C. Small, J.M. Gilligan, and B.A. Ackerly. 2015. Flood risk of natural and embanked landscapes on the Ganges-Brahmaputra tidal delta plain. Nature Climate Change 5 (2): 153-157. https://doi.org/10.1038/ nclimate2472.

Brown, S., and R.J. Nicholls. 2015. Subsidence and human influences in mega deltas: The case of the Ganges-Brahmaputra-Meghna. Science of the Total Environment 527: 362-374. https://doi.org/10.1016/j.scitotenv.2015.04.124.

BWDB. 2012. Annual flood report 2012. Dhaka: Bangladesh Water Development Board (BWDB). http://www.ffwc.gov.bd/index.php/reports/annual-floodreports. Accessed 9 May 2016.

Church, J.A., P.U. Clark, A. Cazenave, J.M. Gregory, S. Jevrejeva, A. Levermann, M.A. Merrifield, G.A. Milne, R.S. Nerem, P.D. Nunn, A.J. Payne, W.T. Pfeffer, D. Stammer, and A.S. Unnikrishnan. 2013. Sea level change. In Climate change 2013: The physical science basis. Contribution of working group I to the fifth assessment report of the Intergovernmental Panel on Climate Change, ed. T.F. Stocker, D. Qin, G.-K. Plattner, M. Tignor, S.K. Allen, J. Boschung, A. Nauels, Y. Xia, V. Bex, and P.M. Midgley. Cambridge, UK/New York: Cambridge University Press.

Dasgupta, S., M. Huq, Z.H. Khan, M.M.Z. Ahmed, N. Mukherjee, M.F. Khan, and K. Pandey. 2014. Cyclones in a changing climate: The case of Bangladesh. Climate and Development 6 (2): 96-110. https://doi.org/10.1080/17565529 .2013.868335.

Haque, A., M. Salehin, and J.U. Chowdhury. 2002. Effects of coastal phenomena on the 1998 flood. In Engineering concerns of flood: A 1998 perspective, ed. M.A. Ali, S.M. Seraj, and S. Ahmad. Dhaka: Directorate of Advisory, Extension and Research Services, Bangladesh University of Engineering and Technology.

Haque, A., S. Sumaiya, and M. Rahman. 2016. Flow distribution and sediment transport mechanism in the estuarine systems of Ganges-Brahmaputra-Meghna delta. International Journal of Environmental Science and Development 7 (1): 22-30. https://doi.org/10.7763/IJESD.2016.V7.735. 
Huq, S., S.I. Ali, and A.A. Rahman. 1995. Sea-level rise and Bangladesh: A preliminary analysis. Journal of Coastal Research SI 14: 44-53.

Islam, A.K.M.S., and J.U. Chowdhury. 2002. Hydrologic characteristics of the 1998 flood in major rivers. In Engineering concerns of flood: A 1998 perspective, ed. M.A. Ali, S.M. Seraj, and S. Ahmad. Dhaka: Directorate of Advisory, Extension and Research Services, Bangladesh University of Engineering and Technology.

Kay, S., J. Caesar, J. Wolf, L. Bricheno, R.J. Nicholls, A.K.M.S. Islam, A. Haque, A. Pardaens, and J.A. Lowe. 2015. Modelling the increased frequency of extreme sea levels in the Ganges-Brahmaputra-Meghna delta due to sea level rise and other effects of climate change. Environmental Science-Processes and Impacts 17 (7): 1311-1322. https://doi.org/10.1039/c4em00683f.

Milliman, J.D., J.M. Broadus, and G. Frank. 1989. Environmental and economic implications of rising sea level and subsiding deltas: The Nile and Bengal examples. Ambio 18 (6): 340-345.

Nihal, F., M. Sakib, W.E. Elahi, A. Haque, M. Rahman, and R.A. Rimi. 2015. Sidr like cyclones in Bangladesh coast. 2nd International Conference on Environment, Technology and Energy, November 22-23, Colombo.

Nihal, F., M. Sakib, S. Noor, A. Haque, M. Rahman, W.E. Elahi, and U. Halder. 2016. Climatic impacts on the fluvial and tidal inundation patterns in the Ganges-Brahmaputra-Meghna delta. Proceedings of the 2016 International Conference on Disaster Management and Civil Engineering (ICDMCE'2016), April 12-13, Kyoto.

Sakib, M., F. Nihal, A. Haque, M. Rahman, and M. Ali. 2015. Sundarban as a buffer against storm surge flooding. World Journal of Engineering and Technology 3: 59-64. https://doi.org/10.4236/wjet.2015.33C009.

Whitehead, P.G., E. Barbour, M.N. Futter, S. Sarkar, H. Rodda, J. Caesar, D. Butterfield, L. Jin, R. Sinha, R. Nicholls, and M. Salehin. 2015a. Impacts of climate change and socio-economic scenarios on flow and water quality of the Ganges, Brahmaputra and Meghna (GBM) river systems: Low flow and flood statistics. Environmental Science-Processes and Impacts 17 (6): 1057-1069. https://doi.org/10.1039/c4em00619d.

Whitehead, P.G., S. Sarkar, L. Jin, M.N. Futter, J. Caesar, E. Barbour, D. Butterfield, R. Sinha, R. Nicholls, C. Hutton, and H.D. Leckie. 2015b. Dynamic modeling of the Ganga river system: Impacts of future climate and socio-economic change on flows and nitrogen fluxes in India and Bangladesh. Environmental Science-Processes and Impacts 17 (6): 1082-1097. https://doi. org/10.1039/c4em00616j. 
Open Access This chapter is licensed under the terms of the Creative Commons Attribution 4.0 International License (http://creativecommons.org/licenses/ by/4.0/), which permits use, sharing, adaptation, distribution and reproduction in any medium or format, as long as you give appropriate credit to the original author(s) and the source, provide a link to the Creative Commons license and indicate if changes were made.

The images or other third party material in this chapter are included in the chapter's Creative Commons license, unless indicated otherwise in a credit line to the material. If material is not included in the chapter's Creative Commons license and your intended use is not permitted by statutory regulation or exceeds the permitted use, you will need to obtain permission directly from the copyright holder.

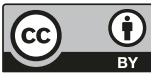

